\title{
POINT PREVALENCE SURVEY OF NOSOCOMIAL INFECTIONS IN UNIVERSITY HOSPITAL IN MARTIN
}

\author{
Malobicka E, Roskova D, Svihrova V, Hudeckova H.
}

Department of Public Health, Jessenius Faculty of Medicine, Comenius University, Martin, Slovak Republic

\section{A b s t r a c t}

Nosocomial infections are a serious problem not only in Slovakia but in all countries. The European Commission decided on their standardized surveillance in the whole European Union. According methodology elaborated by experts from the European Centre for Disease Control and Prevention in Stockholm we performed a point prevalence survey in the University Hospital Martin.

Our observed prevalence of nosocomial infections in University Hospital Martin within the point prevalence study was $5.2 \%$.

The highest point prevalence of nosocomial infections was found at the Surgical Department (9.3\%). The most common type of nosocomial infections was urological infections (27.3\%), sepsis (22.7\%) and surgical site infection $(22.7 \%)$.

The most common microorganisms isolated from the biological material were Klebsiella pneumoniae, Pseudomonas aeruginosa and Proteus mirabilis. Appropriate method of nosocomial infections surveillance is monitoring their prevalence in the point prevalence studies. International projects of nosocomial infections in the EU allow to compare the obtained results with other hospitals in the Member States.

Key words: nosocomial infection, prevalence, ECDC

\section{INTRODUCTION}

Nosocomial infections (NI) in Slovakia are obligatory notifiable.

Regulation of the Ministry of Health of the Slovak Republic No. 553/2007 on requirements for healthcare facilities about health protection, sets for providers of healthcare and for healthcare workers a duty to avoid NI and to register NI in patient records and in a diary of NI.

To take measures to reduce their occurrence based on the results of the analysis. An important role plays also the continuous education of employees (1).

The aim of this study was to analyze the incidence of NI through point prevalence study on inpatient care of University Hospital Martin (UHM).

\section{METHODS}

Material consisted of obtained data through point prevalence studies (PPS - Point prevalence survey).

Prevalence indicates the number of all diseases (newly created or incurred in the past, but persistent) in a given population. To the point prevalence study were included all inpatients at a given time in the hospital or at selected departments (2).

PPS has been described in the protocol, drawn up by experts from the European Centre for Disease Prevention and Control (ECDC). An infection is considered as NI if it occurs on or after 3rd hospital day since hospital admission. Infection was present at the time of monitoring, or signs and symptoms were present in the past and the patient was still in the follow-up of anti-infective therapy.

Data were collected by questionnaire aimed to determine the incidence and type of NI, including the etiological agent according to the protocol definitions (3).

Ad dress for correspond e n c e:

Mgr. Eva Malobicka, PhD., Department of Public Health JFM CU, Sklabinska Str. N. 26, 03601 Martin,

Slovak Republic; e-mail: evka.malobicka@gmail.com. 
We used the definitions of different types of NI from the Codebook by ECDC.

Data collection for each department was required to begin and end in one day, with a maximum duration the whole hospital for 2-3 weeks (3). The survey was realized from June 4th till June 18nd, 2012.

Our team consisted of researchers from the Department of Public Health of the Jessenius Faculty of Medicine, Comenius University, Regional Public Health Authority in Martin and the University Hospital Martin. We visited in three weeks according a set schedule all inpatient departments of the hospital and in collaboration with appointed doctors at the wards they assessed data from patient records.

We recorded patient data (age, sex, date of hospitalization), introduced invasive devices and the use of antibiotics. We examined the presence of hospital infection (as defined study), date of birth, localization of infection and microorganisms isolated from biological material.

To the survey were incluted all pacients admitted to the ward before 8.00 am and not discharged from the ward at the time of the survey were included.

Patients who underwent invasive surgery on the monitored day, patients from outpatient facilities, patients in the emergency room and dialysis patients were excluded (3).

For privacy protection, every patient in the survey was given a code and his/her data were registered in database only under this code.

The results were processed, analyzed and statistically evaluated in Microsoft Excel. We considered as significant differences in the level of statistical significance $\mathrm{p}<0.05$.

\section{RESULTS}

There were 422 patients included in the survey, 218 woman (51.7\%) and 204 men (48.3\%). Range of the file was from $0-99$ years (Median $=60$ years, Modus $=74$ years, $\mathrm{SD}=21.7$ ).

We recorded 22 nosocomial infections, accounting for $5.2 \%$ of the total number of patients enrolled in the study. Range of the patients with nosocomial infection was (15-84 years) $($ median $=73$ years, modus $=77$ years, $\mathrm{SD}=16.5)$. Nosocomial infection was recorded in $59.1 \%$ of women (13 NI) and $40.9 \%$ of men (9 NI). The first signs of NI were mostly recorded from the fourth to sixth day of hospitalization, at $31.8 \%$, as well as for hospitalization lasting for more than 13 days.

Figure 1 shows the prevalence of nosocomial infections in the University Hospital Martin

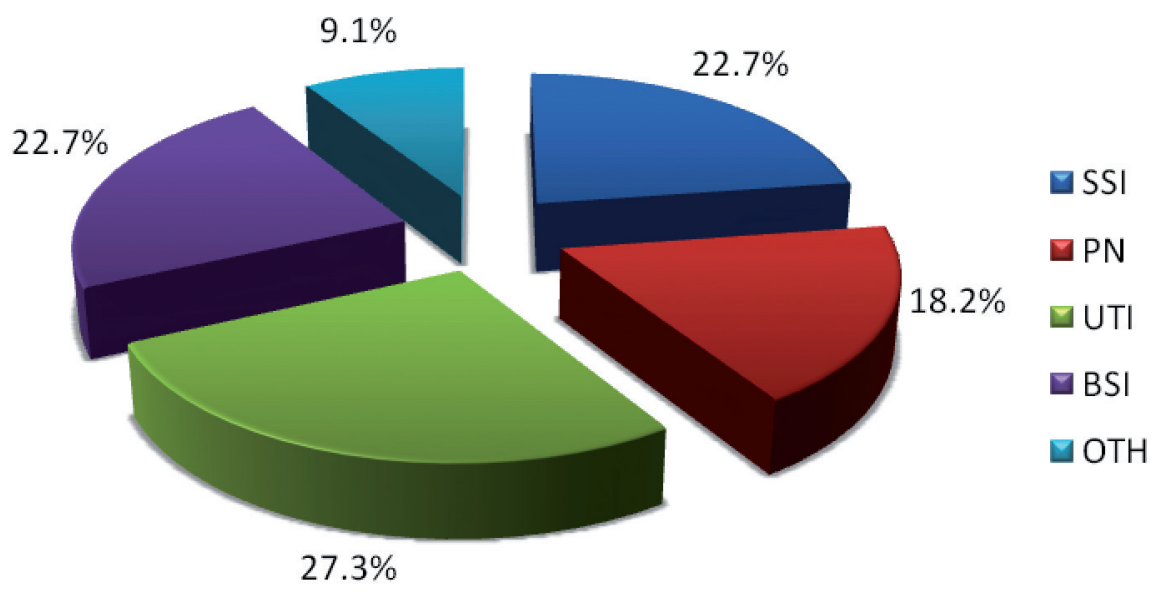

Fig. 1 Prevalence of nosocomial infections in the University Hospital Martin, point prevalence survey 2012. (n=22) According CDC definitions: SSI - Surgical site infections; PN - Pneumoniae; UTI - Urinary tract infections; BSI Bloodstream infections; OTH - others. 
The largest proportion of NI represented urinary tract infections in $27.3 \%$ (6 cases). They represented $22.2 \%$ ( 2 cases) in males of the total number of detected NI, while in women $30.8 \%$ ( 4 cases). There were also blood stream infections and surgical site infections, which were represented in the same number $22.7 \%$ (5 cases). Blood stream infections were found in men in $11.1 \%$ ( 1 case), and in women in $30.8 \%$ (4 cases). Surgical site infections represented $22.2 \%$ ( 2 cases) in men, $23.0 \%$ ( 3 cases) in women of the total number of detected NI. Pneumonia represented $18.2 \%$ of NI (4 cases) in men occurred in $33.4 \%$ (3 cases), in female $7.7 \%$ ( 1 case). Other infections represented $9.1 \%$ of NI ( 2 cases). We included skin, bone and joint infections within this group. Statistically significant differences between men and women were not found ( $\mathrm{p}>0.05)$.

Figure 2 presents incidence of NI according to age group.

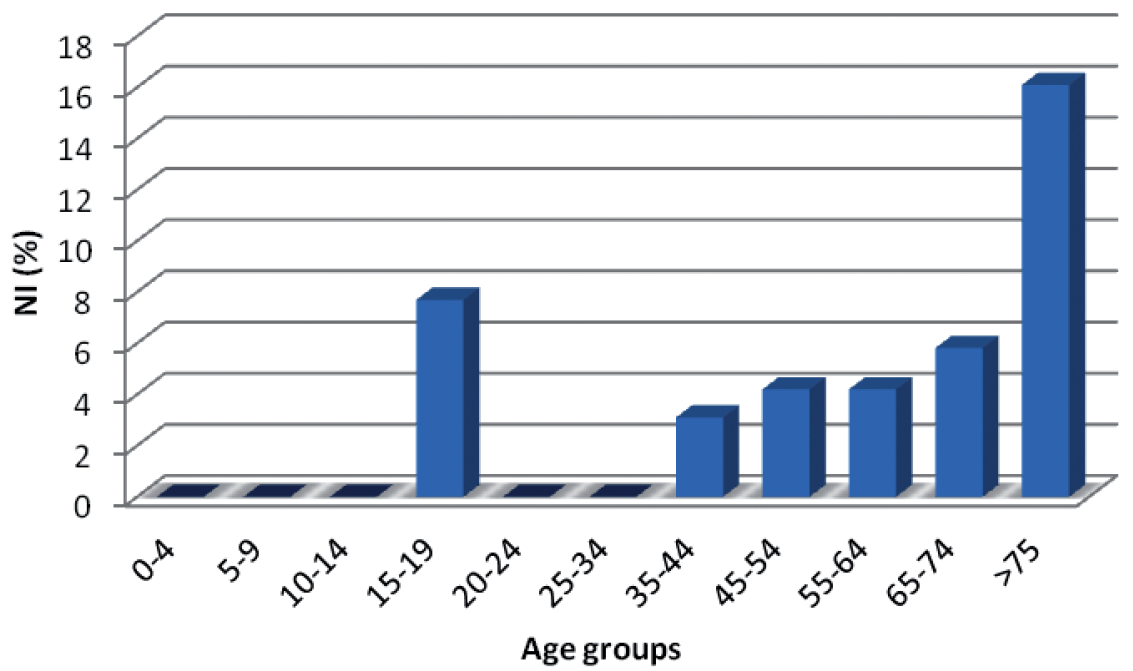

Fig. 2 Prevalence of nosocomial infections in the University Hospital Martin (point prevalence survey 2012) according age groups.

The highest incidence was recorded in the age group 75 - 84 years (10 cases), representing a prevalence of $16.1 \%$ of all hospitalizations in this age group. Monitored higher incidence was not statistically significant $(p>0.05)$ in comparison with other age groups. In the age group less than 14 years has not been found any nosocomial infections.

In the following table we have indicated the prevalence of nosocomial infections, antibiotic use and introduced invasive devices according to specialization of the department.

At least one nosocomial infection had $5.2 \%$ of all patients, ranging from $4.2 \%$ at the conservative departments to $9.3 \%$ at the surgical departments.

At least one antibiotic was taken by 164 patients, which represents prevalence of $38.9 \%$. The biggest prevalence (56.5\%) was found at paediatric departments and intensive care units.

Invasive devices had the highest percentage (72.5\%) in patients hospitalized at internal departments. Prevalence of NI in relation to the introduced invasive device was recorded on surgical department (15.1\%).

The following table shows the distribution of microorganisms isolated from nosocomial infections by type of infection. 
Table 1 Prevalence of nosocomial infections, antibiotic use and introduced invasive devices according to specialization of department. (University Hospital Martin, point prevalence survey 2012).

\begin{tabular}{|l|c|c|c|c|c|c|c|c|c|c|}
\hline \multirow{2}{*}{ Specialty } & \multicolumn{9}{|c|}{ Surveyed patients } & \multicolumn{3}{c|}{ Invasive devices } \\
\cline { 2 - 12 } & \multicolumn{2}{|c|}{ All patients } & \multicolumn{2}{c|}{$\begin{array}{c}\text { Patients with } \\
\text { HAIs }\end{array}$} & $\begin{array}{c}\text { Patients with } \\
\text { antimicrobial } \\
\text { use }\end{array}$ & \multicolumn{2}{c|}{$\begin{array}{c}\text { Surveyed } \\
\text { patients }\end{array}$} & \multicolumn{2}{c|}{$\begin{array}{c}\text { Patients } \\
\text { with HAIs }\end{array}$} \\
\cline { 2 - 13 }$y$ & $\mathrm{~N}$ & $\%$ & $\mathrm{~N}$ & $\%$ & $\mathrm{n}$ & $\%$ & $\mathrm{n}$ & $\%$ & $\mathrm{n}$ & $\%$ \\
\hline Surgery & 118 & 27.9 & 11 & 9.3 & 43 & 36.4 & 73 & 61.9 & 11 & 15.1 \\
\hline Medicine & 167 & 39.6 & 7 & 4.2 & 76 & 45.6 & 121 & 72.5 & 7 & 5.8 \\
\hline Paediatrics & 23 & 5.4 & 1 & 4.3 & 13 & 56.5 & 13 & 56.5 & 1 & 7.7 \\
\hline $\begin{array}{l}\text { Intensive Care } \\
\text { Units }\end{array}$ & 46 & 10.9 & 3 & 6.6 & 26 & 56.5 & 31 & 67.4 & 3 & 9.7 \\
\hline Gynaecology & 15 & 3.6 & 0 & 0.0 & 1 & 6.7 & 8 & 53.3 & 0 & 0.0 \\
\hline Psychiatry & 35 & 8.3 & 0 & 0.0 & 2 & 5.7 & 0 & 0.0 & 0 & 0.0 \\
\hline Other & 18 & 4.3 & 0 & 0.0 & 3 & 16.7 & 5 & 27.8 & 0 & 0.0 \\
\hline Total & 422 & 100.0 & 22 & 5.2 & 164 & 38.9 & 220 & 52.1 & 22 & 10.0 \\
\hline
\end{tabular}

Table 2 Microorganisms isolated from nosocomial infections by type of infection. University Hospital Martin, point prevalence survey 2012. ( $\mathrm{n}=29)$

According CDC definitions: PN - Pneumoniae; SSI - Surgical site infections; UTI - Urinary tract infections; BSI Bloodstream infections; OTH - others.

\begin{tabular}{|l|c|c|c|c|c|c|}
\hline Localization of infection & $\begin{array}{c}\text { All types of } \\
\text { infection } \\
\mathbf{n}(\%)\end{array}$ & $\begin{array}{c}\text { PN } \\
\text { Isolated microorganisms }\end{array}$ & $\begin{array}{c}\text { SSI } \\
\mathbf{n}(\%)\end{array}$ & $\begin{array}{c}\text { UTI } \\
\mathbf{n}(\%)\end{array}$ & $\begin{array}{c}\text { BSI } \\
\mathbf{n}(\%)\end{array}$ & $\begin{array}{c}\text { OTH } \\
\mathbf{n}(\%)\end{array}$ \\
\hline Klebsiella pneumoniae & $6(20.7)$ & 0.0 & 0.0 & $2(33.3)$ & $2(22.2)$ & $2(40.0)$ \\
\hline Proteus mirabilis & $6(20.7)$ & 0.0 & $1(12.5)$ & $3(50.0)$ & $1(11.1)$ & $1(20.0)$ \\
\hline Pseudomonas aeruginosa & $6(20.7)$ & 0.0 & $3(37.5)$ & $1(16.7)$ & $1(11.1)$ & $1(20.0)$ \\
\hline Enterococcus faecalis & $2(6.9)$ & 0.0 & 0.0 & 0.0 & $1(11.1)$ & $1(20.0)$ \\
\hline Enterococcus sp. & $2(6.9)$ & 0.0 & $2(25.0)$ & 0.0 & 0.0 & 0.0 \\
\hline Streptococcus pyogenes & $2(6.9)$ & 0.0 & 0.0 & 0.0 & $2(22.2)$ & 0.0 \\
\hline Candida albicans & $1(3.4)$ & $1(100.0)$ & 0.0 & 0.0 & 0.0 & 0.0 \\
\hline E coli & $1(3.4)$ & 0.0 & 0.0 & 0.0 & $1(11.1)$ & 0.0 \\
\hline Enterobacter cloacae & $1(3.4)$ & 0.0 & $1(12.5)$ & 0.0 & 0.0 & 0.0 \\
\hline Klebsiella oxytoca & $1(3.4)$ & 0.0 & $1(12.5)$ & 0.0 & 0.0 & 0.0 \\
\hline Staphylococcus aureus & $1(3.4)$ & 0.0 & 0.0 & 0.0 & $1(11.1)$ & 0.0 \\
\hline Microorganisms, total & $29(100.0)$ & $1(100.0)$ & $8(100.0)$ & $6(100.0)$ & $9(100.0)$ & $5(100.0)$ \\
\hline HAIs, total & $22(100.0)$ & $4(18.2)$ & $5(22.7)$ & $6(27.3)$ & $5(22.7)$ & $2(9.1)$ \\
\hline HAIs with microorganisms & $16(72.7)$ & $1(25.0)$ & $4(80.0)$ & $5(83.3)$ & $4(80.0)$ & $2(100.0)$ \\
\hline
\end{tabular}


From the people with NI were isolated 29 microorganisms, at least $(25.0 \%)$ in cases of pneumonia and the most (100.0\%) in cases of other infections. The most common organisms isolated were Klebsiella pneumoniae, Pseudomonas aeruginosa and Proteus mirabilis. The most frequently cultured Proteus mirabilis (50.0\%) and Klebsiella pneumoniae (33.3\%) were in the cases of urinary tract infections, which were also the most common type of NI. Pseudomonas aeruginosa was most frequently isolated in cases of surgical site infections $(37.5 \%)$. Biological material for cultivation was not collected in 6 cases of NI (27.3\%).

\section{DISCUSSION}

Nosocomial infection in the Slovak legislation is defined as an infection of the internal or external origin, which was causally linked to the performance or stay in hospital or social services (4).

ECDC defines a nosocomial infection as infections arising in the hospital, were not present on admission, and the patient was not in admission in the incubation period of the infection. When the incubation period is not known as nosocomial infections are considered those that occurred after more than 48 to 72 hours after admission to the medical facility. Infection present at the time of admission may be considered as nosocomial only if it is epidemiologically associated with previous hospitalization. In addition to defined NI have the Center for Disease Control and Prevention, USA (CDC) accurate diagnostic criteria for different types of infections. Using the same criteria and methods of surveillance allows the comparability of the collected data (5).

NI are always accompanied by the provision of health care and are common cause of morbidity and mortality in hospitalized patients worldwide (6).

ECDC estimates that in Europe in the hospitals acquired NI approximately 4.1 million patients. Deaths that occur as a direct result of these infections is estimated at least 37000 (7).

Podstatova states that incidence of NI in hospitals is estimated between 5 to $10 \%$ on surgical departments. On the surgical departments the incidence may be higher as 30\%. The intensive care unit is recorded up to $20 \%$ of nosocomial infections (8).

The basic premise for the suppression of NI is the accurate accounting and analysis. The incidence of NI is in Slovakia currently reported to the EPIS (Epidemiological Information System).

Analysis of NI is annually published in the Annual Report about the activities of the Public Health Authorities of the Slovak Republic, published by the Public Health Authority of the Slovak Republic. Since 2006 are published data on hospital-acquired infections at the website of EPIS.

The incidence of NI is still lower than is expressed in the literature.

Currently, the average incidence of NI in hospitalized patients in hospitals in developed countries ranges from 6-8\%. In less developed countries, it is even more than 25\%. Disease, death, and economic costs associated with acquired NI are increasing especially in the last thirties. Although estimates of the proportions of preventable NI are different, there is a general agreement that it may be more than 20\% in developed countries and in less developed even more than $40 \%$ of NI $(7,9)$.

The authors Sramova et al. states that incidence of the NI in the Czech Republic is from 1.36 to $2.80 \%$, depending on the nature of department (10). An estimated incidence of NI in USA is 2 million per year (11).

Within the EU are NI monitored within the HAI Net (Healthcare-associated Infections Surveillance Network), European network for monitoring the NI. The network is coordinated by the ECDC. The priority of HAI-Net is a coordination of European research point-prevalence study and use of antimicrobials in acute care hospitals, incidence and the prevalence of NI and use of antimicrobial agents in the long-term care facilities (12). 
Within the incidence surveillance are monitored NI on the intensive care units and also surgical site infections. This data collection is timed, personnel and financial more difficult as prevalence monitoring, therefore, it is usually performed only in selected high-risk units or limited on time or reference to selected infections.

Pilot point prevalence study was carried out in 2010. Based on the results the experts from the European Centre for Diseases Prevention and Control and the experts from European Union Member States developed point-prevalence study protocol, which was scheduled for June $2012(13,14)$.

In Europe 63 hospitals of 22 countries participate on the pilot point prevalence study. The study involved 17,900 patients. The prevalence of NI in the EU represented $7.1 \%(15,16)$.

Pilot point prevalence study was carried out in the Slovak Republic in two hospitals, in University Hospital Martin and in Hospital and Policlinic in Komárno (16, 17).

In the study were included all inpatient departments of the UHM. The national point prevalence studies were performed in EU in 2012 based on the recommendations from the pilot point-prevalence study.

In UHM we found 22 nosocomial infections in the performed point prevalence study which represented prevalence $5.2 \%$.

The prevalence in pilot prevalence study in the UHM in 2010 was $5.5 \%$ (17).

Found prevalence in the UHM is comparable with other European studies, where the prevalence ranges from 3.5 to $10.5 \%$ NI $(18,19,20)$.

But our detected incidence is lower than the prevalence of NI in participating European countries through pilot point prevalence study in which the prevalence of NI was $7.1 \% \mathrm{NI}$ (15).

The largest proportion of NI in the prevalence study were urinary tract infections, than surgical site infections and bloodstream infections. Bloodstream infections and urinary tract infections were the most common reported infections in the pilot prevalence study. The most common location of NI in the pilot prevalence study in Europe, were respiratory infection (25.7\%), surgical site infections (17.2\%) and urinary tract infections (17.2\%). Blood stream infections represented $14.2 \%(15)$.

Dominated infection in men in the point prevalence study (2012) were pneumonia, while in the pilot prevalence study (2010)dominated blood stream infections. The largest percentage of $\mathrm{NI}$ in women in both studies had urinary tract infections.

Complexity and invasiveness of interventions is reflected in the largest incidence of nosocomial infections in surgical departments.

We recorded the highest prevalence of NI, so the number of NI of all hospitalized patients on the surgical departments (9.3\%), than intensive care units (6.6\%). Different results were in the national pilot prevalence study (2010) were the highest prevalence were on the intensive care units (20.0\%), pediatric departments $(6.3 \%)$ and on the surgical departments were recorded $5.6 \%$ of NI. Similar to that in Slovakia also in Europe most of NI occurred in the intensive care units $(28.1 \%)$, than surgical departments $(7.8 \%)$ and geriatric departments $(6.6 \%)(15,16)$.

In the point prevalence study (2012) 164 patients were taking antibiotics (38.9\%) from all hospitalized patients in the UHM (422). The most common indications for the treatment were community infections and prophylactic use of antibiotics. In the national pilot prevalence study (2010) $31.5 \%$ of patients were taking antibiotics. The most common indication was prophylactic use of antibiotics (42\%) and than treatment of community infection (40\%). Similar results are also found in the European pilot prevalence study in which antibiotics were taking by $34.6 \%$ of patients. The most common indication for antibiotic use was therapy of infections (66.4\%), mainly treatment of community infections (41.3\%). Prophylactic antibiotic use was found in $30.7 \%$ of administered antibiotics $(15,16)$.

The most common etiologic agents were Klebsiella pneumoniae, Pseudomonas aeruginosa and Proteus mirabilis. Biological material for cultivation was not collected in the 6 cases $(27.3 \%)$. The largest number was in cases of pneumonia $(75 \%)$. 
In the national pilot prevalence study (in 2010) were detected the same etiological agents. From the biological material were frequently cultured Klebsiella $s p$. (23.1\%) then Pseudomonas aeruginosa and Candida sp. both of which have $11.5 \%$.

In the data from the surveillance of NI in Europe through a pilot point prevalence study were between the most common proven causative agents Escherichia coli (15.2\%), Staphylococcus aureus (12.1\%) and Pseudomonas aeruginosa (11.2\%). Escherichia coli was most frequently isolated from urinary tract infections (37.1\%), Staphylococcus aureus was most frequently isolated from surgical site infections (21.5\%), and Pseudomonas aeruginosa from respiratory infections (17.7\%). Etiologic agent has not been demonstrated in up to $40.9 \%$ of NI, mostly in the gastrointestinal (59.7\%) and in respiratory infections (51.5\%) (15, 16).

Results from point prevalence study point out still persisted problem of inadequate reporting of NI from the UHM departments. After implementation of the pilot point prevention study in 2010 occurred the decrease of reporting in 2011 and 2012. The importance of NI is underestimated, which can result in risk to patient lives. In relation to the development of NI is necessary to think about the increased cost of diagnosis and treatment of the disease, the costs of operating departments, salaries of medical personnel, losses in relation to suffering of the patient, reducing their quality of life and prolonged sick leave. This could be an argument for the management of healthcare facilities to support NI surveillance system. It is still necessary to emphasize the principles of asepsis and antisepsis, observe hygiene epidemiological regime, in order to greatest possible use precautionary principle in health care and prevention of NI, perform permanent training of all medical staff in the NI and in the case of suspected NI their timely report. If you are departments, clinics and medical facilities to treat nosocomial infections rational, can they manage to reduce their occurrence. If will departments, clinics and medical facilities approach to the nosocomial infections rational, they can manage reduce their incidence.

\section{CONCLUSION}

Prevalence surveillance of NI is appropriate, personnel and economically burdensome method of monitoring nosocomial infections compared with incidental surveillance. Our detected prevalence of NI approached to the incidence in other EU countries.

Good surveillance allows to detect early beginning or imminent problem that can cause expending higher finance costs and risks of patient's life.

International projects of nosocomial infections in the EU allow to compare the obtained results with other hospitals in the Member States.

\section{REFERENCES}

1. Vyhláška MZ SR č. 553 / 2007 Z.z. ktorou sa ustanovujú podrobnosti o požiadavkách na prevádzku zdravotníckych zariadeni $z$ hladiska ochrany zdravia.

2. Ducel, G.,Fabry, J., Nicolle, L. Prevention of hospital-acquired infections. A practical guide. 2 vyd. WHO, 2002. 64 s. [online ]. [cit. 2011-09-10]. Dostupné na internete:

http://www.who.int/csr/resources/publications/drugresist/whocdscsreph200212.pdf

3. European Centre for Disease Prevention and Control. Point prevalence survey of healthcareassociated infections and antimicrobial use in European acute care hospitals - protocol version 4.3. Stockholm: ECDC; 2012. ISBN 978-92-9193-366-2

4. Zákon NR SR č. 355/2007 Z.z. o ochrane, podpore a rozvoji verejného zdravia a o zmene a doplnení niektorých zákonov. 2007. Zbierka zákonov, 2007. Čiastka 154. 2402-75.

5. Centers for Disease Control and Prevention: Definitions Of Nosocomial Infections. [online] [cit. 2009-03-10] Dostupné na internete: <http://www.health2k.state.nv.us/sentinel/Forms/UpdatedForms 105/CDC_Defs_Nosocomial.pdf

6. Murajda L., Šulaj M., Hudečková H., Litvová S., Buchancová J. Healthcare-associated infections at intensive care unit of department of anesthesiology and intensive medicine at Martin Faculty Hospital. In Central European Journal of Public Health. 2010, 18 (3): 174 - 178. 
7. European Centre for Disease Prevention and Control. Surveillance of healthcare - associated infections in Europe, 2007. Stockholm: ECDC, 2012. ISBN 978-92-9193-327-3

8. Podstatová, H. Základy epidemiológie a hygieny. Praha: Galén, 2009. str. 152. ISBN 978-80-7262-597-0.

9. Mad’ar R., Piezgová L. 2008. MRSA v domovech pre seniory. Existuje dúvod pro obavy? In Nozokomiálne nákazy. ISSN 1336-3859, 2008, roč. 7, č 3, s. 1-8.

10. Šrámová H. a kol. 1995. Nozokomiální nákazy. Praha: MAXDORF, 1995. s. 224. ISBN 80-85912-00-7.

11. Burke J. P. 2003. Infection control - a problem for patient safety. In The new England Journal of Medicine. Február 2003, 348(7):651-6

12. European Centre for Disease Prevention and Control. European network for the surveillance of healthcare-associated infections (HAI), Stockholm: ECDC. 2009 [online]. [cit. 2012-01-20]. Dostupné na internete: http://ecdc.europa.eu/en/activities/surveillance/hai/pages/default.aspx

13. European Centre for Disease Prevention and Control. Point Prevalence Survey of Healthcare-Associated Infections and Antimicrobial Use in European Acute Care Hospitals, Protocol 4.2 - Codebook, ECDC, máj 2011

14. Suetens, C., Goossens, H. Analysis of Pilot PPS data. New Strategies to Monitor and Control Infections, Antibiotic use and Resistance in Healthcare Facilities in the EU Member States, 2010.

15. Zarb, P. et al. Pilot point prevalence survey of healthcare - associated infections and Antimicrobials use. In Eurosurveillance. 2012, 17 (47). Available from: http: / /www.eurosurveillance.org/ViewArticle.aspx?ArticleId=20316

16. Litvová S., Štefkovičová M., Kološová A., Murajda L. Výsledky pilotnej bodovej prevalenčnej štúdie nozokomiálnych nákaz v SR, Donovaly 2011, XIV. Ročník odbornej konferencie Surveillance nemocničných nákaz $\mathrm{v}$ zdravotnickych zariadeniach, CD zborník

17. Žabková, E. - Murajda, L. - Hudečková, H. Point prevalence survey of nosocomial infections in University Hospital in Martin, In Acta Medica Martiniana, 2011, 11/1, s. 35 - 40. ISSN: 1335-8421.

18. Lanini, S. et al., Healthcare-associated infection in Italy: Annual point - prevalence surveys, 2002 - 2004. In: Infect Control Hosp Epidemiol. 2009, 30 (7):659-65.

19. European Centre for Disease Prevention and Control. 2008. Annual epidemiological report on communicable diseases in Europe 2008. Stockholm: ECDC; 2008. Available from:

http://ecdc.europa.eu/en/publications/Publications/0812_SUR_Annual_Epidemiological_Report_2008.pdf

20. Reilly, J. a kol. 2008. Results from the Scottish national HAI prevalence survey. J Hosp Infec. 2008, 69:62-8.

Received: January, 31, 2013

Accepted: May, 2, 2013 